\title{
A deterministic worldview promotes approval of state paternalism
}

\author{
Ivar Hannikainen ${ }^{\mathrm{a}}$, Gabriel Cabrala, Edouard Macheryc, Noel Struchiner ${ }^{\mathrm{a} 1}$
}

\begin{abstract}
The proper limit to paternalist regulation of citizens' private lives is a recurring theme in political theory and ethics. In the present study, we examine the role of beliefs about free will and determinism in attitudes toward libertarian versus paternalist policies. Throughout five studies we find that a scientific deterministic worldview reduces opposition toward paternalist policies, independent of the putative influence of political ideology. We suggest that exposure to scientific explanations for patterns in human behavior challenges the notion of personal autonomy and, in turn, undermines libertarian arguments against state paternalism appealing to autonomy and personal choice.
\end{abstract}

Keywords: scientific determinism; paternalism; libertarianism; public policy; autonomy; folk metaphysics.

When Michael Bloomberg, former New York City Mayor, proposed a 16-ounce limit on soft drink size, public response split neatly into two opposing factions. Critics denounced the bill's flagrant disregard for personal autonomy and choice ("Don't let bureaucrats tell you what size beverage to buy"), while supporters enumerated the public health risks of sugar overconsumption: diabetes, heart disease, obesity, and so on. The tension between these distinct moral motives, autonomy and welfare, has fueled a productive and longstanding debate on the proper limits of state paternalism (Dworkin, 1972; Feinberg, 1971; Mill, 1869; Sunstein \& Thaler, 2003; Thaler \& Sunstein, 2008).

Attitudes toward paternalism represent a particular puzzle for existing approaches to political psychology. In several contexts, conservatives have been found to trust and respect authority more than liberals (e.g., believing that authorities are "generally right about things," obeying orders even if one disagrees with them; see Altemeyer, 1973; Graham, Haidt \& Nosek, 2009). Some theories propose that submission to authority may satisfy needs for order and structure (Jost et al., 2003), with external systems such as God and the government compensating for the subjective lack of personal control and order (Kay et al., 2008). Yet, in the context of paternalism, these roles are reversed: Conservatives repudiate authoritarian control while liberals defend it. So, why might liberal and conservative attitudes reverse in this specific context?

One reason may be that paternalist policies - such as the regulation of health care and retirement, for instance - often have a redistributive flavor since the self-directed harm and the irrational behavior of a minority are paid for by society at large. This redistributive flavor may be unpalatable to conservatives who hold a stronger belief that the world is inherently just (Lerner, 1980).

In the present paper, we pursue a distinct, but complementary explanation. Advocates of a libertarian state argue that paternalist regulation violates personal autonomy, but appeals to personal autonomy and liberty depend on certain assumptions concerning free will and determinism. So the present study examines the role of beliefs about free will and determinism in attitudes toward paternalist regulation. Below, we review a handful of recent studies that demonstrate the pervasive influence of metaphysical beliefs on interpersonal behavior in order to contextualize and motivate this suggestion.

The belief in free will is widespread (Nichols \& Knobe, 2007) across cultures (Sarkissian et al., 2010) and fulfills certain social purposes: Free-will beliefs are strengthened by the desire to punish others' immoral behavior (Clark et al., 2014), while a deterministic perspective mitigates punishment (Aspinwall, Brown \&

\footnotetext{
1 a Department of Law, Pontifical Catholic University of Rio de Janeiro (Brazil). b Department of Law, Fundação Getulio Vargas (Brazil).

c Department of History and Philosophy of Science, University of Pittsburgh (USA).

This research was supported in part by grants from the National Council for Scientific and Technological Development (CNPq) and the Carlos Chagas Filho Research Support Foundation (FAPERJ).

Correspondence concerning this article should be addressed to Ivar Hannikainen, Department of Law, Rua Marquês de São Vicente, 225, Gávea, Rio de Janeiro, Brazil, 22451-900. Contact: ivar.hannikainen@gmail.com

We thank James Andow and Guilherme de Almeida for comments on previous versions of this manuscript. This research was supported in part by grants from the National Council for Scientific and Technological Development (CNPq) and the Carlos Chagas Filho Research Support Foundation (FAPERJ). Neither funding source was involved in study design.
} 
Tabery, 2012; Monterosso, Royzman \& Schwartz, 2005), particularly by sapping retributive motives (Carey \& Paulhus, 2013; Shariff et al., 2014).

Though the belief in free will may play a valuable role, neuroscientists argue that its scientific grounds are shaky (Bargh, 2008; Crick, 1995; Gazzaniga, 2011; Pinker, 2002; Wegner, 2002), although philosophers are more circumspect (Mele, 2014; Nahmias, 2014). A series of influential studies in neuroscience seems to directly challenge the existence of free will by pointing to neural activity that precedes the volition to act (Haggard, Clark, \& Kalogeras, 2002; Libet et al., 1983; but see Schultze-Kraft et al., 2016). A more extensive research program establishes innumerable influences of genes, brain structures, childhood experience, and our physical environments on decision-making, personality, politics, and success.

Although we cannot establish a causal link, views on the 'locus of control' have shifted together with the expansion of the behavioral sciences. Between 1960 and 2002, the belief that people are themselves in control of their outcomes has given way to a belief that external circumstances shape people's outcomes (Twenge, Zhang, \& Im, 2004), a trend which may be partly attributable to the dissemination of scientific evidence for determinism (Saint-Paul, 2011).

In sum, if deterministic thinking threatens the ordinary notion of personal autonomy, and an appeal to autonomy subserves the rejection of state paternalism, we should expect that a deterministic worldview reduces opposition to paternalist policies. We first provide cross-sectional evidence of a link between locus of control and political preferences, using a large and diverse sample of United States adults (Study 1) and two student samples in Brazil (Studies 2 and 3). Next, in two experiments we manipulate belief in scientific determinism and observe its effects on the assessment of libertarianism and paternalism in the abstract (Study 4) and as reflected by concrete policies (Study 5). We report all procedures, measures, and exclusions throughout our studies. Based on a small-to-moderate effect sizes and statistical power at .80, we estimated and met minimum required sample sizes for every main analysis in Studies 1 through 5.

\section{Study 1}

\section{Methods}

As our starting point in Study 1, we examine whether locus of control predicts beliefs about the role of government in private life, using a heterogeneous sample of 3,184 United States adults (1,569 females, age $_{\text {mean }}=53$ years) recruited in a nationwide telephone survey conducted by the Pew Research Center (2014). Five proxy variables were identified, but we report only the clearest test of our hypothesis in the main text. (See Supplementary Analysis 1 for converging evidence from the remaining four proxy variables).

People with an internal locus of control believe that they can control the events that happen to them, while people with an external focus of control believe that the events that happen to them are determined by external factors that are beyond their control (Rotter, 1966; James, 1973). While the locus-of-control construct is not identical to the belief-in-free-will construct (Waldman, Viney, Bell, Bennett, \& Hess, 1983), the two are related (Stroessner \& Green, 1990; Paulhus \& Carey, 2011): People who believe in free will often have an internal locus of control, while believers in determinism tend to have an external locus of control.

If beliefs in free will and/or indeterminism underlie opposition to paternalist policies, an internal locus of control should be linked to a preference for libertarian policies. Meanwhile, paternalist breaches of autonomy may be less objectionable from the perspective of an external locus of control, according to which factors beyond one's personal control regularly shape one's outcomes.

As part of a battery of questions, subjects were asked to endorse either a libertarian (O: "It's not the government's job to protect people from themselves") or a paternalist (1: "Sometimes laws to protect people from themselves are necessary") view of government. In two questions, respondents were also asked whether willpower or forces outside one's control determine success in life - serving as our proxy measures of locus of control (Rotter, 1966).

\section{Results}

To begin with, we examined the locus of control items independently. As predicted, the belief that $\left(\mathrm{LC}_{1}\right)$ "hard work and determination are no guarantee of success" was linked to greater support for paternalism than the view that "people who want to get ahead can make it if they're willing to work hard", $\chi^{2}(1,3,088)=51.5, p<.0001, \varphi=.13$. Similarly, those who believed that $\left(\mathrm{LC}_{2}\right)$ "success in life is pretty much determined by forces outside of our control" expressed greater endorsement of a paternalist government 
than those who believed that "everyone has it in their own power to succeed", $\chi^{2}(1,3,029)=35.9, p<.0001$, $\varphi=.11$.

The correlation between an external locus of control and support for paternalism may be due to a common cause, in particular, to political orientation. To control for this possibility, we investigate whether political orientation and locus of control exert independent effects on views about paternalism. A mixed effects logistic model predicted attitudes toward paternalism from $\mathrm{LC}_{1}, \mathrm{LC}_{2}$, the $\mathrm{LC}_{1} \times \mathrm{LC}_{2}$ interaction, and a series of demographic measures entered as covariates: age, gender (1: female; 0: male), educational attainment, religiosity, annual personal income (\$10,000 brackets), political orientation (continuous), and race (categorical), allowing the intercept to vary randomly by state (see Supplementary Analysis 1 for model summary).
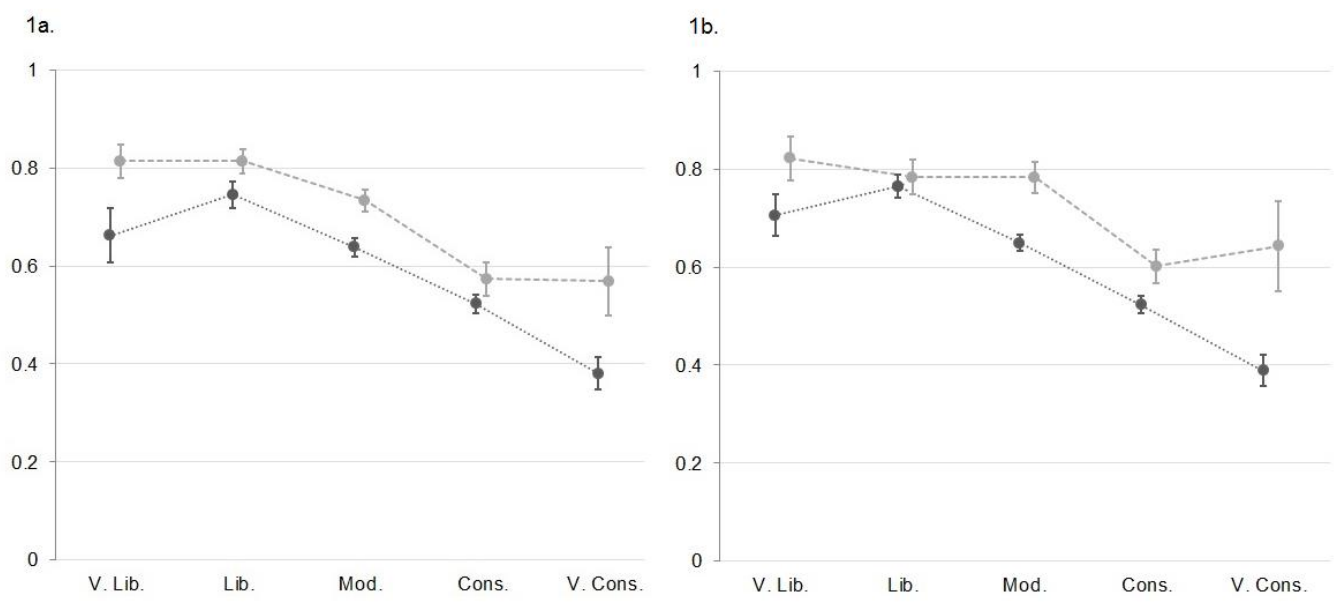

Figures $1 \mathrm{a}$ and $1 \mathrm{~b}$. Proportion of paternalists by locus of control items (internal: grey-dashed; external: blackdotted) and political orientation ( $x$-axis).

The influence of both locus of control items on paternalism remained significant, $\left(\mathrm{LC}_{1}\right) \mathrm{B}=.401, \mathrm{SE}$ $=.111, \mathrm{OR}=1.49, p=.001 ;\left(\mathrm{LC}_{2}\right) \mathrm{B}=.359, \mathrm{SE}=.180, \mathrm{OR}=1.43, p=.046$, indicating that an external locus of control predicted approval of paternalism and that this relationship was independent of political orientation. In order to visualize these separate effects, we plot the proportion of paternalists by political orientation and locus of control items in Figures 1a and 1b. Corresponding analyses of attitudes toward specific regulation surrounding healthcare and retirement savings, for instance, revealed similar effects of locus of control beliefs: An external locus of control was linked to the preference for paternalist over libertarian government programs (see Supplementary Materials).

\section{Discussion}

Study 1 provides indirect evidence that beliefs about free will and determinism underlie views about the role of government: As predicted by past research on the correlation between belief in determinism and locus of control, individuals with an external locus of control were more likely to endorse state paternalism, whereas individuals with an internal locus of control tended to endorse a libertarian government. Moreover, although the role of government is a matter of political disagreement, the relationship with locus of control was not explained by differences in political ideology.

Studies 2 and 3 directly test the prediction that beliefs in free will and determinism underlie the preference for, respectively, libertarian and paternalist policies. First, both libertarian scholars (Hayek, 1960; Rothbard, 1978) and voters (Iyer, Koleva, Graham, Ditto, \& Haidt, 2012) advocate minimal state regulation of citizen's behavior based largely on a categorical defense of individual freedom.

A second line of reasoning predicts that believing that human behavior is determined reduces people's objection to state paternalism (Saint-Paul, 2011; Sunstein, \& Thaler, 2003). Individuals with a deterministic worldview, who readily grant a broad influence of external factors on human decision-making, may be more likely to condone paternalist limitations on their behavior.

In Studies 2 and 3, we investigate the relationship between participants' evaluations of libertarian and paternalist policy proposals about canonical issues in the debate (such as the pension system, health care, and suicide) and their beliefs about free will and determinism using a validated scale of beliefs in free will and determinism (FAD-Plus: Paulhus \& Carey, 2011). 


\section{Study 2}

\section{Methods}

Study 2 employed an online sample of 164 undergraduate students $(102$ female, age mean $=22$ years $)$ from three local universities in Rio de Janeiro, Brazil, who participated in exchange for course credit. In the first section, participants were asked to imagine the following hypothetical situation:

Imagine you are a citizen of Country C. In Country C, lawe are approved for a 10-year period. After a law expires, it is reviewed, either to be ratified for another 10-year period or replaced by a new bill submitted by a member of Congress. Bills are voted on by citizens via the Internet, and the proposals with the best citizen evaluations become laws, while the rest are discarded.

In order to capture the tension between a preference for autonomy versus societal welfare, three proposals were described which varied in the restrictions they imposed on individual liberty and autonomy, and in the efficiency with which they addressed the issue at hand.

A libertarian bill was characterized by few or no restrictions and the least efficiency (e.g., cigarettes sold with a health advisory and a $20 \%$ reduction in smoking). A hard paternalist bill, by contrast, was characterized by heavy-handed restrictions resulting in the greatest efficiency (e.g., prohibition of cigarette sales with a near $100 \%$ reduction in smoking). The soft paternalist option offered a compromise: some restrictions with moderate efficiency in addressing the policy issue at hand (e.g., difficult purchasing procedure with a $60 \%$ reduction).

Participants viewed six policy issues in a randomized order and voted for one of the bills (libertarian, soft paternalist, or hard paternalist) related to the each of the issues. Next, participants completed the Free Will and Scientific Determinism subscales of FAD-Plus Scale (Paulhus \& Carey, 2011). Two unrelated scales $^{2}$ were administered in conjunction, the results of which are reported here in Supplementary Analysis 2. On the final page, participants optionally reported their age, gender, and political orientation on separate five-point scales for social and fiscal issues.

\section{Results}

The distribution of responses by vignette is provided in Table 1. Beliefs in free will and scientific determinism were negatively correlated, $r(164)=-.156, p=.047$. We replicated also the correlation between a conservative political orientation and free-will beliefs, social: $r(164)=.353, p=.0001$, fiscal: $r(163)=.232$, $p=.003$ (Carey \& Paulhus, 2013). Political orientation did not predict belief in scientific determinism however, $p \mathrm{~s}>.3$.

Table 1. Distribution of responses by proposal type: frequency (percentage).

\begin{tabular}{llll}
\hline & Hard paternalism & Soft paternalism & Libertarianism \\
\hline Cigarette sales & $10(6 \%)$ & $59(36 \%)$ & $95(58 \%)$ \\
\hline Pension system & $58(35 \%)$ & $80(49 \%)$ & $26(16 \%)$ \\
Untested medicine & $89(54 \%)$ & $30(18 \%)$ & $45(27 \%)$ \\
Speed control & $122(74 \%)$ & $16(10 \%)$ & $26(16 \%)$ \\
Suicide & $16(10 \%)$ & $24(15 \%)$ & $124(76 \%)$ \\
Traffic management & $9(5 \%)$ & $68(41 \%)$ & $87(53 \%)$ \\
\hline
\end{tabular}

To assess the relationship between free-will and scientific-determinism beliefs and vote-type, we conducted mixed-effects, ordered logistic regressions predicting vote-type (0: libertarian, 1: soft paternalist, 2: hard paternalist), with policy issue as random effect. Separate models with (Model 2) and without (Model 1) demographic measures were estimated (see Table 2). In order to facilitate comparisons between effect

${ }^{2}$ The specific measures employed were the Social Value Orientation task (Murphy, Ackermann, \& Handgraaf, 2011) and the Need for Cognition scale (Cacioppo, Petty, \& Kao, 1984). 
sizes, we z-scored beliefs in free will and in scientific determinism, as well as self-reported political orientation.

Was a libertarian voting pattern linked to the belief in free will? We found no evidence for this relationship; rather, the observed trend ran counter to our prediction. By contrast, the hypothesis that paternalist votes would be linked to a belief in scientific determinism received clear support: Determinists were more likely to endorse paternalist policies, $\mathrm{OR}=1.25, p=.001$, even after controlling for all other demographic variables, $\mathrm{OR}=1.27, p<.001$.

Table 2. Ordinal regression models of vote type.

\begin{tabular}{|c|c|c|c|c|c|c|c|c|}
\hline \multirow[b]{3}{*}{ Model variables } & \multicolumn{4}{|c|}{$\begin{array}{l}\frac{\text { Model } 1}{\text { Wald } \chi^{2}}(2)=16.08, p=.0003, \mathrm{n}= \\
164\end{array}$} & \multicolumn{4}{|c|}{$\begin{array}{l}\frac{\text { Model } 2}{\text { Wald } \chi^{2}}(6)=26.98, p=.0001, \mathrm{n}= \\
163\end{array}$} \\
\hline & \multirow{2}{*}{$O R$} & \multicolumn{2}{|c|}{$C I(95 \%)$} & \multirow{2}{*}{$p$} & \multirow{2}{*}{$O R$} & \multicolumn{2}{|c|}{$C I(95 \%)$} & \multirow{2}{*}{$p$} \\
\hline & & Lower & Upper & & & Lower & Upper & \\
\hline \multicolumn{9}{|l|}{ FAD+ } \\
\hline Free will* & 1.18 & 1.04 & 1.34 & .010 & 1.12 & .968 & 1.29 & .130 \\
\hline $\begin{array}{l}\text { Scientific } \\
\text { determinism* }\end{array}$ & 1.26 & 1.10 & 1.43 & .001 & 1.27 & 1.12 & 1.45 & .000 \\
\hline \multicolumn{9}{|l|}{ Political orientation } \\
\hline Social issues* & & & & & 1.22 & 1.03 & 1.44 & .019 \\
\hline Economic issues* & & & & & .849 & .721 & 1.00 & .050 \\
\hline \multicolumn{9}{|l|}{ Demographics } \\
\hline Age & & & & & 1.01 & .985 & 1.03 & .459 \\
\hline Gender & & & & & 1.35 & 1.02 & 1.78 & .034 \\
\hline
\end{tabular}

*: z-scored. OR: odds ratio; CI: confidence interval; $p$ : significance value; FAD+: Freedom and Determinism Plus Scale.

Finally, we flipped the model in order to visualize differences in beliefs about free will and determinism, as well as political orientation by vote-type. Employing mixed-effects linear regression models, we estimated the marginal effects of soft and hard paternalist votes on each standardized dependent measure (relative to libertarian votes). We plot these marginal effects in Figure 2. Belief in scientific determinism emerged as the only significant differences in both hard and soft paternalist votes, relative to libertarian votes.

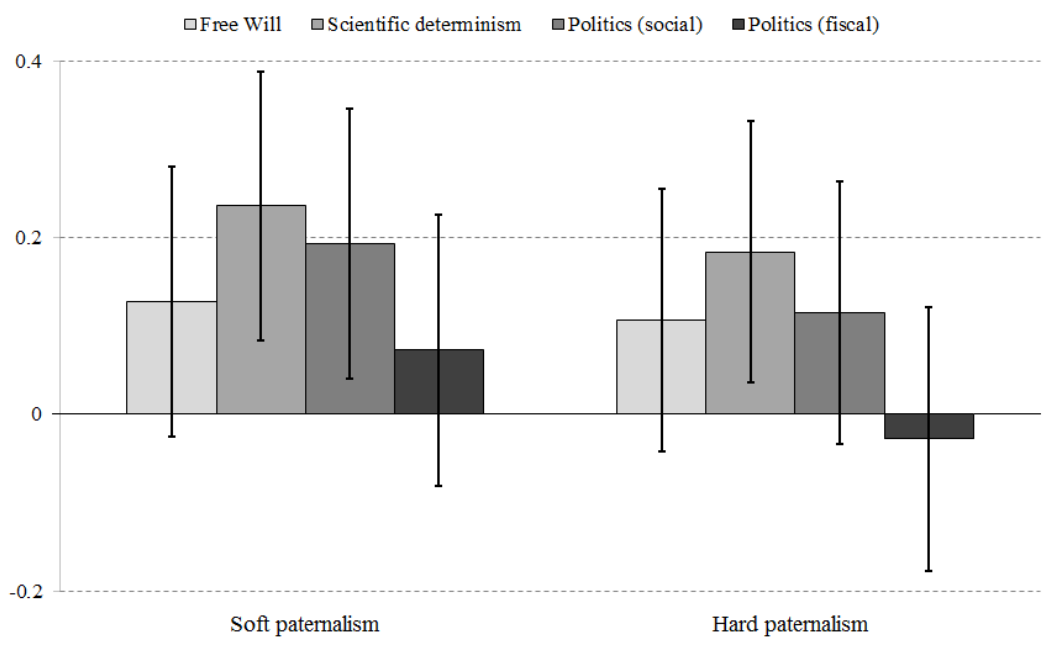


Figure 2. Marginal effects of political orientation and free will and scientific determinism beliefs on vote type. (Error bars represent 95\% confidence intervals.)

\section{Discussion}

In line with the second line of reasoning proposed above, the belief in scientific causes of human behavior was associated with the endorsement of paternalist policies addressing public policy issues such as the pension system, cigarette smoking, and the use of untested drugs.

By contrast, the prediction that a belief in free will would be linked with support for libertarian policies was not supported. Rather, free-will beliefs were equally compatible with paternalist and libertarian policies in our sample. This is consistent with the findings reported in Section 1: Stroessner and Green (1990) find that locus of control, which predicts support for paternalist policies independent of political orientation in Study 1, correlates with the belief in determinism (see also Waldman et al., 1983), but not with the belief in free will, while Paulhus and Carey (2011) report that belief in determinism correlates positively with external locus of control and negatively with internal locus of control, while belief in free will correlates only with internal locus of control: Locus of control thus seems more closely associated with determinism than with belief in free will.

We also observed inconsistent effects of political orientation across Studies 1 and 2. In Study 1, conservatism was associated with a preference for small government, while in Study 2 the opposite was true (particularly, in relation to the social dimension of political ideology). Crosscultural differences in political ideology may explain this difference: Possibly individual liberties are more strongly protected by the political right in the United States, but by the political left in Brazil. In any case, whereas political ideology had varied effects on attitudes toward the role of government, the relationship with the belief in determinism was consistent across both studies.

\section{Study 3}

\section{Methods}

A volunteer sample of 90 undergraduate law students $\left(64\right.$ females, age $e_{\text {mean }}=19$ years) at the Pontifical Catholic University of Rio de Janeiro participated in this study after class. Participants viewed a subset of three policy issues considered canonical in the debate on state paternalism: Suicide, Cigarette Sales, and Pension System. For each issue, participants independently evaluated the policy alternatives on a sevenpoint scale from -3: "Strongly oppose" to 0: "Neither oppose nor support", 3: "Strongly support". Next, participants completed the updated seven-item Scientific Determinism subscale, and optionally reported their age and gender.

Study 3 makes two meaningful contributions beyond the straightforward replication of Study 2 . First, by eliciting independent ratings of paternalist and libertarian policies, we aim to understand whether deterministic thinking is linked to the approval of paternalist policies, the rejection of libertarian policies, or manifests both relationships to some degree. Second, we contrast two types of determinist beliefs. On one hand, situationist beliefs about the influence of the physical environment (e.g., "Science has shown how your past environment created your current intelligence and personality") may straightforwardly correlate with pro-paternalism attitudes: In many circumstances, design choices are inevitable - e.g., opt-in or opt-out programs for organ donations or savings plans - and the recognition that physical environments make a difference one way or another may be enough to tilt preferences toward beneficial alternatives (Thaler \& Sunstein, 2003).

Yet scientific determinism may yield support for paternalism more indirectly as well. Perhaps, the categorical protection of personal autonomy depends on the conviction that our desires, goals, and personalities reflect our authentic selves. Meanwhile, learning about scientific explanations of human behavior and personality may lead people to dismiss desires, goals, and personalities as reflections of their authentic selves. Thus, if our desires, goals, and personalities are in part the products of our biology, we may be less willing to defend them so adamantly even at a great cost to our own good. Intrinsic determinist beliefs (e.g., "Your genes determine your future") provide a critical test: We should observe no relationship with these items if approval of paternalist policies derives simply from the situationist insight that environment shapes behavior.

\section{Results}


Libertarian bills received the greatest approval $(\mathrm{n}=89, \mathrm{M}=1.08, \mathrm{SD}=1.00)$, followed by weak paternalist bills $(\mathrm{n}=88, \mathrm{M}=0.40, \mathrm{SD}=1.20)$. Hard paternalist bills dipped below the midpoint $(\mathrm{n}=89, \mathrm{M}$ $=-.35, \mathrm{SD}=1.24)$, indicating a general tendency towards disapproval. Paired $t$-tests suggested that differences in approval between bill types were moderate to large $(.61<$ all $\beta \mathrm{s}<1.26)$, and highly statistically significant, all $p \mathrm{~s}<.0001$.

Table 3. Correlation matrix between determinism beliefs and evaluation of policy proposals.

\begin{tabular}{|c|c|c|c|c|}
\hline & (SD) & $(\mathrm{L})$ & $(\mathbf{S P})$ & (HP) \\
\hline Scientific determinism (SD) & - & & & \\
\hline Libertarian policies (L) & $\begin{array}{l}.101 \\
.35 \\
89\end{array}$ & - & & \\
\hline Soft paternalist policies (SP) & $\begin{array}{l}.264 \\
.013 \\
88\end{array}$ & $\begin{array}{l}.197 \\
.067 \\
87\end{array}$ & - & \\
\hline Hard paternalist policies (HP) & $\begin{array}{l}-.024 \\
.83 \\
89\end{array}$ & $\begin{array}{l}-.229 \\
.032 \\
88\end{array}$ & $\begin{array}{l}.178 \\
.10 \\
87\end{array}$ & - \\
\hline
\end{tabular}

Values shown are the correlation coefficients $(r)$, statistical significance $(p)$ and pairwise sample $(n)$ for each analysis.

We examined the correlations between policy ratings and the belief in scientific determinism. As expected, belief in scientific determinism was associated with higher ratings of soft paternalist policies (see Table 3). A multivariate linear regression controlling for participant gender and age predicting libertarian, soft paternalist, and hard paternalist policies confirmed this result: $\beta=.301, \mathrm{t}=2.67, p=.009$. In corresponding models of libertarian and hard paternalist policies, determinist beliefs did not predict policy ratings $p s \geq .43$ (see Table 4 ).

Table 4. Multivariate regression model of libertarian (L), soft paternalist (SP), and hard paternalist (HP) policy $\operatorname{ratings}(\mathrm{N}=80)$.

\begin{tabular}{llll}
\hline & $(\mathrm{L})$ & $(\mathrm{SP})$ & $(\mathrm{HP})$ \\
& $\mathrm{RMSE}=1.04$ & $\mathrm{RMSE}=.968$ & $\mathrm{RMSE}=1.02$ \\
& $\mathrm{r}^{2}=.01$ & $\mathrm{r}^{2}=.11$ & $\mathrm{~F}=.03$ \\
& $\mathrm{~F}=.277$ & $\mathrm{~F}=3.10$ & $\mathrm{~F}=.926$ \\
$\mathrm{p}=.84$ & $\mathrm{p}=.032$ & $\mathrm{p}=.43$ \\
\hline Scientific determinism $^{\mathrm{a}}$ & $.097(.43)$ & $.301(.009)$ & $-.022(.85)$ \\
\hline Age $^{\mathrm{b}}$ & $-.021(.72)$ & $.037(.50)$ & $.057(.32)$ \\
Gender & $-.005(.99)$ & $.384(.14)$ & $.409(.14)$ \\
\hline Constant & $.388(.74)$ & $-.995(.37)$ & $-1.40(.23)$ \\
\hline
\end{tabular}

a: standardized coefficient; b: un-standardized coefficient. ( $P$ values are presented in brackets.)

Finally, we separated environmental and intrinsic determinism beliefs, and examined their independent relationships to evaluations of soft paternalist policies. Belief in environmental causes of behavior $(\mathrm{M}=2.81, \mathrm{SD}=.68)$ was greater than belief in genetic and biological determinism $(\mathrm{M}=2.28, \mathrm{SD}$ $=.68)$ in a paired sample $t$-test, $t(86)=5.76, p=.0001$, Cohen's $d=.78$, and both sub-indices predicted evaluations of soft paternalist policies, environmental $r(86)=.26, p=.018$; biological $r(88)=.21, p=.048$. 


\section{Discussion}

Replicating the results of Study 2, participants' belief in scientific determinism correlated with their endorsement of soft paternalist solutions, such as opt-out systems, strategic placement of recommended choices, and obstruction toward detrimental choices. In contrast with Study 2, determinists did not show greater support for heavy-handed paternalist legislation, such as the criminalization of suicide or a ban on cigarettes. Study 3 employed a subset of the policy issues in Study 2, which makes it hard to interpret this null result. However, even in Study 2, scientific deterministic beliefs were more strongly associated with soft paternalist votes than with hard paternalist votes.

Preliminary evidence indicated that the influence of deterministic beliefs on attitudes toward public policy is not explained solely by the recognition that environmental manipulations could yield improvements in human behavior. Belief in intrinsic determinants of behavior, like genes and the brain, predicted support for paternalist nudges as well.

\section{Does the induction of a determinist worldview favor paternalist policies?}

In this section, we examine whether the acquisition of a deterministic worldview induces support for paternalist regulation. We have provided two explanations for this link: one, based on the efficacy of environmental manipulations, and another, based on disbelief in personal autonomy. It is also possible, though, that political preferences and attitudes toward scientific explanations of human behavior are due to a common cause, without being causally related to each other. Studies 4 and 5 adopt an experimental approach in order to assess whether inducing a deterministic worldview influences preferences concerning paternalist versus libertarian legislation.

\section{Study 4}

\section{Methods}

We invited 135 law students ( 74 females; age mean $=26$ years) to participate in a survey after class. Participants were randomly assigned to read one of three 800-word essays, and answer four comprehension questions about their specific essay.

Two essays were titled "The science of behavior: Why do we act the way we do?". In the intrinsic condition, the essay reported findings in behavioral genetics (De Neve, 2011; Koopmans et al., 1995) and neuroscience (Burns \& Swerdlow, 2003; Casey et al., 2011; Kanai et al., 2011; Knoch et al., 2006) that support the conclusion that "our genes and the structure of our brains affect our behavior and decisionmaking to a greater extent than we might imagine." The essay in the environmental condition reported findings in developmental (Lewis-Morrarty et al., 2015; Madestam \& Yanagizawa-Drott, 2011; Raby et al., 2014; Noble et al., 2015) and social psychology (Ariely, 2008; Haviland-Jones et al., 2005; Helzer \& Pizarro, 2011), that show how "childhood experiences and apparently trivial features of the environment affect our behavior and decision-making to a greater extent than we might imagine." Finally, a third control essay titled "The science of the mind: How does consciousness work?" discussed visual attention and consciousness (Koch, 2006).

Under the pretense of a separate poll, a confederate then handed out a survey about "Society, the State and the Individual" which presented the following passage:

"It is often argued that the State has several functions: on one hand, to protect citizen autonomy, that is, to preserve people's right to decide freely about their lives; on the other, to promote welfare, that is, to promote certain social goods such as education, security, happiness and health. However, sometimes citizens in the exercise of their autonomy make decisions against their own welfare (e.g., harmful to their health, with great risks and/or excessive costs in the long run, etc.). In circumstances like these, the government can pass laws that (A) uphold citizens' autonomy, even if doing so comes at a cost to societal welfare, or (B) promote societal welfare, even if doing so undermines citizens' autonomy.

In your opinion, to what extent should the government promote (A) citizens' autonomy or (B) citizens' welfare in these situations?"

The dependent measure for this study was the relative importance of autonomy versus welfare considerations in public policy, using a bipolar six-point scale from (1): "Only A" to (6): "Only B". Finally, participants provided basic demographic information (age, gender and political orientation) as in Study 2. 
By exposing participants to a set of deterministic findings, we sought to temporarily induce greater belief in scientific determinism and assess its influence on judgments about the relative importance of autonomy and welfare considerations in public policy. Critically, we separated findings that emphasize the influence of environmental and developmental factors from findings that emphasize the role of genes and the brain, in order to follow up on the distinction between situational and intrinsic types of deterministic belief.

\section{Results}

Mean responses by condition are reported in Table 5. In one-way ANOVAs we observed no demographic differences by group, all $p \mathrm{~s} \geq .34$. However, beliefs about the role of government significantly differed by condition, $\mathrm{F}(2,179)=13.08, p<.0001, \eta^{2}=.129$.

Table 5. Relative importance of autonomy and welfare by condition.

\begin{tabular}{|c|c|c|c|c|}
\hline & & $\mathrm{N}$ & M & $\mathrm{SD}$ \\
\hline (1) & Control & 66 & 2.94 & 1.12 \\
\hline$(2)$ & Developmental \& Social Psychology & 59 & 3.73 & 0.96 \\
\hline (3) & Behavioral Genetics Eे Neuroscience & 54 & 3.80 & 1.02 \\
\hline
\end{tabular}

As expected, participants in the control condition believed that the government should respect personal autonomy more than it should maximize societal welfare, one-sample vs. 3.5: $t(66)=-4.06, p=.0001$, $d=.50$. Post hoc tests were conducted using Tukey's HSD correction in order to investigate the effects of our manipulations: Participants' beliefs about the role of government were influenced by exposure to deterministic findings in social/developmental psychology, $t=4.24, p<.001, d=.75$, and in behavioral genetics and neuroscience, $t=4.49, p<.001, d=.80$, relative to the control group.

\section{Discussion}

In an experimental setting we observed an influence of exposure to scientific evidence for determinism on attitudes toward the role of government. Participants in the control group reported the belief that personal autonomy matters more than societal welfare in public policy. However, exposure to the results of a handful of behavioral-science studies shifted participants' preferences toward paternalism. Consistent with Study 3, both intrinsic and situational determinism reduced the opposition to paternalist regulation.

In the present study, we examined political preferences by describing the contours of the paternalism debate in abstract terms. In Study 5, we return to specific policy issues in order to examine the corresponding effect of a deterministic worldview on concrete evaluations of paternalist policies.

\section{Study 5}

\section{Methods}

257 volunteers (103 females; age $\mathrm{e}_{\text {mean }}=26$ years) were contacted through a mailing list of participants in previous lab research and invited to participate in a short online survey. In a 2 (policy type: paternalist vs. libertarian) $\times 2$ (universe: deterministic vs. indeterministic) between-subjects design, participants read a description of either a deterministic or indeterministic universe and then evaluated three public policy proposals in a fictional country within said universe.

On the first page, we introduced participants to a fictional universe in which everything that happens is strongly determined by what happened previously, "including/except human decision-making. In this universe, research has shown that genetic, environmental and biological factors greatly influence the way humans behave and make decisions/non-human animals behave, but this is not true of humans" (Nichols \& Knobe, 2007).

Each description went on to list a series of hypothetical findings concerning the influence of genetic, biological, and developmental factors on the behavior of humans (deterministic condition) versus non-human animals (indeterministic condition). The universe description concluded with a recapitulation stating that 
"human decision-making and behavior are shaped primarily by past events beyond their control/the exercise of free will, and that free will/past events exercise(s) only a limited influence".

On the following page, participants read about three draft policies in a democratic nation within the fictional universe. For instance, one case described the public-health burden of excess ultraviolet radiation, causing illness and premature death. Participants in the paternalist condition evaluated a proposal to dissolve a harmless solar protector in the water supply, such that citizens would be automatically protected from ultraviolet radiation by taking a shower. Participants in the libertarian condition evaluated a campaign aimed at informing citizens about the risks of exposure to ultraviolet radiation, and suggested strategies for protecting themselves. Two other issues concerned proposals to combat seasonal food shortages and impulsive shopping in malls (see Appendix). By using hypothetical vignettes, we sought to avoid the noise (ideological commitments, personal history, ingroup bias, etc.) that pervades assessments of real-world issues (e.g., the soda ban, cigarette smoking, pension systems) and provide a cleaner test of judgment and decision-making. Participants evaluated the proposals on an 11-point scale from 0: "total disapproval" to 10: "total approval", and provided basic demographic information as in Studies 2 and 4. We excluded 54 participants $(23 \%)$ who did not finish the survey from subsequent analyses.

\section{Results}

Separate ANOVAs revealed no significant differences in age, political orientation, or in gender distribution by group, all $p s>.30$. Table 6 presents summary statistics of evaluations of policy proposals by condition.

Table 6. Policy evaluations by type and universe: Mean, and standard deviation in brackets.

\begin{tabular}{l|cccc|}
\cline { 2 - 5 } \multirow{2}{*}{$\begin{array}{l}\text { Policy type } \\
\text { Universe }\end{array}$} & \multicolumn{2}{|c|}{ Libertarian } & \multicolumn{2}{c|}{ Paternalist } \\
\cline { 2 - 5 } & $\begin{array}{c}\text { Indeterministic } \\
(\mathrm{n}=46)\end{array}$ & $\begin{array}{c}\text { Deterministic } \\
(\mathrm{n}=50)\end{array}$ & $\begin{array}{c}\text { Indeterministic } \\
(\mathrm{n}=54)\end{array}$ & $\begin{array}{c}\text { Deterministic } \\
(\mathrm{n}=53)\end{array}$ \\
\hline 1: UV radiation & $7.63(2.74)$ & $6.52(2.82)$ & $4.59(3.91)$ & $5.74(3.45)$ \\
\hline 2: Winter food shortage & $6.28(3.28)$ & $5.50(3.22)$ & $4.17(3.33)$ & $4.89(3.21)$ \\
\hline 3: Impulsive shopping & $5.57(3.47)$ & $3.92(3.38)$ & $4.13(3.24)$ & $5.64(3.37)$ \\
\hline
\end{tabular}

Proposal evaluations were positively correlated $(r \mathrm{~s} \geq .25)$, though a reliability analysis indicated poor internal consistency of our composite policy evaluation $(\alpha=.53)$. A two-way ANOVA predicting policy evaluations with policy type, universe, and their interaction as between-subjects factors was significant, $\mathrm{F}(3,199)=7.33, \mathrm{p}=.0004, \eta^{2}=.100$. We observed a main effect of policy type, $\mathrm{F}(1,199)=10.08, p=.0017, \eta^{2}$ $=.048$, and the predicted two-way interaction between universe and policy, $\mathrm{F}(1,199)=12.27, p=.0006, \eta^{2}=$ .058 . 


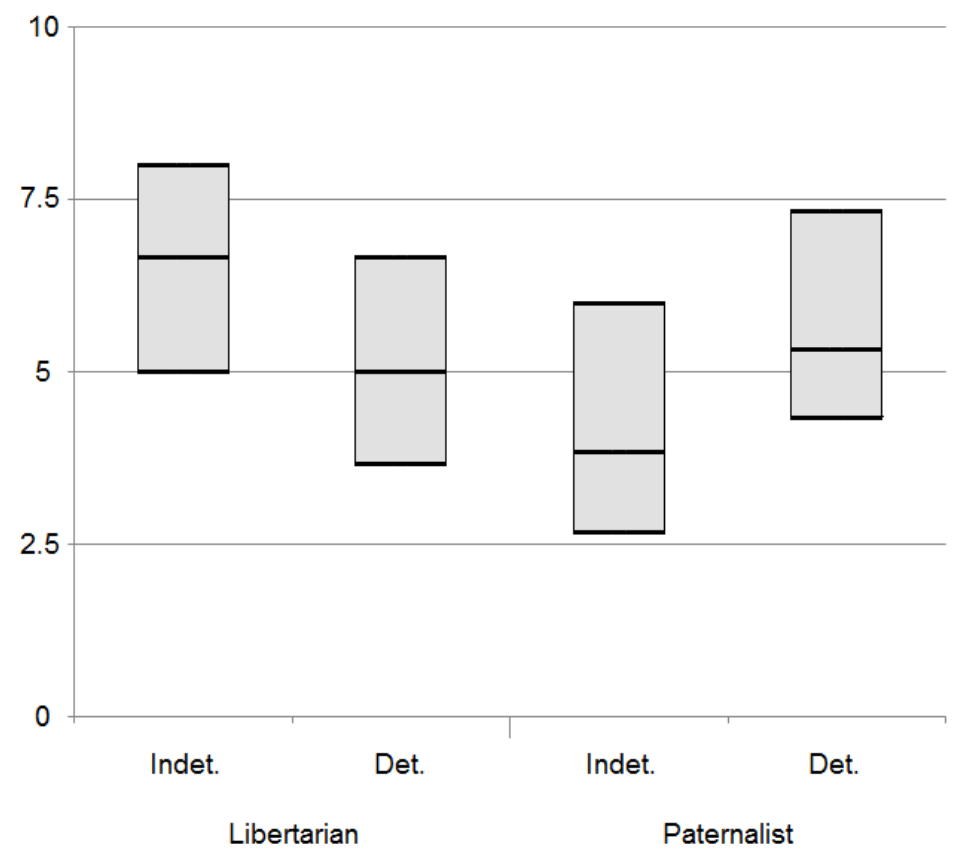

Figure 3. Median and interquartile range of policy evaluations by condition.

Mann-Whitney $\mathrm{U}$ tests were conducted to examine the simple effects of the universe manipulation on libertarian and paternalist policy evaluations. Paternalist policies received greater approval in the deterministic universe than in the indeterministic universe, $\mathrm{z}=-2.58, p=.0099, r=.25$, and libertarian policies exhibited the opposite effect, $\mathrm{z}=2.83, p=.0047, r=-.29$. Figure 3 depicts the median and interquartile range of our composite policy evaluations for each group.

\section{Discussion}

The universe manipulation influenced participants' evaluations of policy proposals: Libertarian policies received greater support in the indeterministic universe than in the deterministic universe, whereas paternalist proposals exhibited the opposite pattern.

In our correlational studies, participants demonstrated ambivalence towards paternalist policies, in contrast with overall approval of libertarian policies. Together with past research showing that people generally believe the universe is indeterministic (Nichols \& Knobe, 2007), Studies 4 and 5 offer evidence of a causal link: The preference for libertarian over paternalist proposals is partly due to a prevailing belief that the world is indeterministic. A deterministic worldview, however, can reduce and even reverse the preference for libertarian over paternalist regulation.

\section{General Discussion}

Paternalism aims to promote societal welfare, and yet the very idea is often met with immediate disdain. Arguments based in rights to personal choice and autonomy thwart all but the most subtle initiatives in choice architecture, even when these demonstrably benefit each of us (Madrian \& Shea, 2000; Thaler \& Benarzi, 2004) and add up to significant aggregate gains for society. Our present research lends some insight into this phenomenon.

Support for a paternalist state was associated with an external locus of control (Study 1), that is, the view that individuals are not themselves in control of their outcomes. Relatedly, individuals with a deterministic worldview were more likely to favor paternalist policies (Study 2), especially in its subtler forms, such as 'nudges' and choice architecture (Study 3). Importantly, this relationship was not explained by differences in political ideology (Studies 1 and 2). No relationship with libertarian policies was observed for the belief in free will (Study 2).

Subsequent experiments provided causal evidence for the role of belief in scientific determinism. A deterministic worldview yielded more favorable attitudes towards paternalism, whether induced by exposure to findings in behavioral science (Study 4) or by placement in a hypothetical deterministic universe (Study 5). Environmental/developmental and genetic/neuroscientific influences on human behavior each reduced 
the opposition to paternalist policies (Study 3) and the relative importance of personal autonomy versus societal welfare in public policy (Study 4).

Learning that environmental factors influence human behavior may straightforwardly yield a preference for beneficial (i.e., paternalist) arrangements of the environment. The reasoning in this case is simple: If we want to boost healthy snack consumption, for instance, and we discover that shelf arrangement affects snack choice (van Kleef, Otten, \& van Trijp, 2012), we can institute a policy that healthy snacks be placed within easier reach. Yet, belief in intrinsic determinants of human behavior, such as genes and the brain, could not have an equally direct effect. We propose a complementary explanation for this result: The defense of personal autonomy depends to some extent on the assumption that an individual's wishes and desires are expressions of their authentic self. Thus, the recognition that beliefs, desires, and behavior are in part the product of situational and intrinsic factors beyond willful control may debunk the ordinary notion of personal autonomy and in turn render paternalist regulation less objectionable.

Some limitations of the present study require specific mention. First, although we attempted to dissociate two potential effects of determinism in Studies 3 and 5, our results were not perfectly consistent. While a deterministic worldview was linked to the approval of paternalist policies in both studies, effects on libertarian policies were mixed: In Study 5, a deterministic-worldview manipulation reduced support for libertarian policies, but no corresponding relationship was observed in a correlational design in Study 3.

Second, participants were often paternalistic about certain issues and libertarian about others, with only a weak inter-correlation of political preferences across issues. Status quo bias - the tendency to support policies already in place - seemingly accounted for the pattern of results in Study 2, yet this issue persisted with our novel, hypothetical policy issues (Study 5). Perhaps our coarse characterization of paternalism overlooked specific features of public policy to which people's judgments were sensitive: such as the content of legislation (i.e., which specific values are promoted: health, money, efficiency, safety, etc.), the target of harm (i.e., whether the regulated behavior harms the self only or affects third parties to some degree also), or the allocation of policy costs (i.e., how policies distribute the costs of harmful behavior throughout society).

In closing, we consider the present findings in a broader theoretical and practical context. First, conservatives in the United States are more likely to distrust science than are liberals (Gauchat, 2012). So, although our focus has been on the implications of behavioral science, a general scientific outlook may also contribute to the liberal preference for evidence-based regulation. Still, the results of Study 4 point toward a unique effect of behavioral science: Exposure to deterministic findings yielded support for paternalism over and above exposure to scientific literature unrelated to the prediction of human behavior. Furthermore, reactions of hostility versus affinity to behavioral scientific evidence and government regulation of private life may jointly depend on epistemic and existential needs (see Hibbing, Smith \& Alfort, 2014; Jost et al., 2003), though this question lies beyond the scope of our paper.

Philosophical reflection is often accused of producing inert knowledge. On the contrary, a budding literature documents various effects of folk metaphysics on interpersonal values and behavior. As noted before, the belief in free will motivates a retributive approach to punishment (Shariff et al., 2014). Meanwhile, views on the self influence generosity and impulsivity: Specifically, a weaker sense of connectedness to one's future self promotes sharing and charitable donations (Bartels, Kvaran, \& Nichols, 2013), but also encourages temporal discounting (Bartels \& Rips, 2010). Finally, reflecting on whether morality is objective (Rai \& Holyoak, 2013) or the product of evolutionary pressures (Paxton, Ungar \& Greene, 2011) influences behavior and moral judgments of others.

As we noted in our opening paragraphs, there are a few indicators that the growth of behavioral science and its always increasing public reception are reshaping our metaphysical convictions and infiltrating policy discussions. Evolutionary biology, cognitive neuroscience, and behavioral genetics challenge the belief in free will, which some behavioral scientists and professional philosophers (Bourget, \& Chalmers, 2014) have done (but see Mele, 2014; Nahmias, 2014). Outside the academic community, deterministic beliefs are now more popular than ever (Twenge et al., 2004). This may be good news, since it means that public reception of socially beneficial institutions - like a penal system geared towards rehabilitation and deterrence (Greene \& Cohen, 2004) or nudges for financial and physical health - will not be met with uncompromising appeals to moral responsibility and personal autonomy. It may also be bad news: Determinism is admittedly hard to stomach, politically divisive, and may legitimize certain anti-social behavior. Therefore, a detailed grasp of the implications of a scientific view of human nature is crucial in order to anticipate the societal consequences of increased public exposure to behavioral science. 


\section{References}

Ariely, D. (2008). Predictably Irrational. New York: Harper Collins.

Bargh, J. A. (2008). Free will is un-natural. In J. Baer, J. C. Kaufman, \& R. F. Baumeister (Eds.), Are we free? Psychology and free will. Oxford University Press.

Bartels, D. M., Kvaran, T., \& Nichols, S. (2013). Selfless giving. Cognition 129, 392-403.

Bourget, D., \& Chalmers, D. J. (2014). What do philosophers believe?.Philosophical Studies, 170(3), 465-500.

Burns, J. M., \& Swerdlow, R. H. (2003). Right orbitofrontal tumor with pedophilia symptom and constructional apraxia sign. Archives of Neurology, 60(3), 437-440.

Cacioppo, J. T., Petty, R. E., \& Kao, C. F. (1984). The efficient assessment of need for cognition. Journal of Personality Assessment, 48, 306-307.

Carey, J. M., \& Paulhus, D. L. (2013). Worldview implications of believing in free will and/or determinism: Politics, morality, and punitiveness. Journal of Personality, 81(2),130-41.

Casey, B. J., Somerville, L. H., Gotlib, I. H., Ayduk, O., Franklin, N. T., Askren, M. K., \& Glover, G. (2011). Behavioral and neural correlates of delay of gratification 40 years later. Proceedings of the National Academy of Sciences, 108(36), 14998-15003.

Clark., C. J., Luguri, J. B., Ditto, P. H., Knobe, J., Shariff, A. F., \& Baumeister, R.F. (2014). Free to punish: a motivated account of free will belief. Journal of Personality and Social Psychology, 106(4), 501-13.

Crick, F. (1995). Astonishing hypothesis: The scientific search for the soul. Simon and Schuster.

De Neve, J. E. (2011). Functional polymorphism (5-HTTLPR) in the serotonin transporter gene is associated with subjective well-being: evidence from a US nationally representative sample. Journal of human genetics, 56(6), 456459.

Dworkin, G. (1972). Paternalism. The Monist, 64-84.

Feinberg, J. (1971). Legal paternalism. Canadian Journal of Philosophy, 1(1), 105-124.

Gauchat, G. (2012). Politicization of science in the public sphere: A study of public trust in the United States, 1974 to 2010. American Sociological Review, 77(2), 167-187.

Gazzaniga, M. (2012). Who's in charge? Free will and the science of the brain. Hachette UK.

Greene, J., \& Cohen, J. (2004). For the law, neuroscience changes nothing and everything. Philosophical Transactions of the Royal Society B: Biological Sciences, 359, 1775-1778.

Haggard, P., Clark, S., \& Kalogeras, J. (2002). Voluntary action and conscious awareness. Nature neuroscience, 5(4), 382385.

Haviland-Jones, J., Rosario, H. H., Wilson, P., \& McGuire, T. R. (2005). An environmental approach to positive emotion: Flowers. Evolutionary Psychology, 3(1), 104-132.

Hayek, F. A. (1960). The constitution of liberty. Routledge \& Kegan Paul.

Helzer, E. G., \& Pizarro, D. A. (2011). Dirty liberals! Reminders of physical cleanliness influence moral and political attitudes. Psychological Science, 22(4), 517-522.

Hibbing, J. R., Smith, K. B., \& Alford, J. R. (2014). Differences in negativity bias underlie variations in political ideology. Behavioral and Brain Sciences, 37(03), 297-307.

Iyer, R., Koleva, S., Graham, J., Ditto, P., \& Haidt, J. (2012). Understanding libertarian morality: the psychological dispositions of self-identified libertarians. PLOS ONE 7(8), e42366.

James, W. H. (1973). Internal versus external control of reinforcement as a basic variable in learning theory. In J. P. Robinson \& P. R. Shaver (Eds.), Measures of social psychological attitudes (pp. 237-243). Ann Arbor, MI: Survey Research Center for Social Research.

Jost, J. T., Glaser, J., Kruglanski, A. W., \& Sulloway, F. J. (2003). Political conservatism as motivated social cognition. Psychological Bulletin, 129(3), 339.

Kanai, R., Feilden, T., Firth, C., \& Rees, G. (2011). Political orientations are correlated with brain structure in young adults. Current biology, 21(8), 677-680.

Kay, A.C., Gaucher, D., Napier, J.L., Callan, M.J., \& Laurin, K. (2008). God and the government: Testing a compensatory control mechanism for the support of external systems. Journal of Personality and Social Psychology, $95,18-35$.

Knoch, D., Pascual-Leone, A., Meyer, K., Treyer, V., \& Fehr, E. (2006). Diminishing reciprocal fairness by disrupting the right prefrontal cortex. Science, 314(5800), 829-832.

Koch, C. (2012). Consciousness: Confessions of a romantic reductionist. MIT press.

Koopmans, J. R., Boomsma, D. I., Heath, A. C., \& van Doornen, L. J. (1995). A multivariate genetic analysis of sensation seeking. Behavior genetics, 25(4), 349-356.

Lewis-Morrarty, E., Degnan, K. A., Chronis-Tuscano, A., Pine, D. S., Henderson, H. A., \& Fox, N. A. (2015). Infant attachment security and early childhood behavioral inhibition interact to predict adolescent social anxiety symptoms. Child Development, 86(2), 598-613.

Libet, B., Gleason, C. A., Wright, E. W., \& Pearl, D. K. (1983). Time of conscious intention to act in relation to onset of cerebral activity (readiness-potential). Brain, 106(3), 623-642.

Madestam, A., \& Yanagizawa-Drott, D. (2011). Shaping the nation: The effect of Fourth of July on political preferences and behavior in the United States. Preprint. 


\section{DETERMINISM \& STATE PATERNALISM}

Madrian, B. C., \& Shea, D. F. (2000). The power of suggestion: Inertia in 401 (k) participation and savings behavior (Tech. Rep.). National Bureau of Economic Research.

Mele, A. (2014). Free: why science hasn't disproved free will. NewYork: Oxford University Press.

Mill, J. S. (1869). On liberty. Longmans, Green, Reader, and Dyer.

Murphy, R. O., Ackermann, K. A., \& Handgraaf, M. (2011). Measuring social value orientation. Judgment and Decision Making, 6(8), 771-781.

Nahmias, E. (2014). Is free will an illusion? Confronting challenges from the modern mind sciences. In W. SinnottArmstrong (Ed.), Moral psychology, vol. 4: Freedom and responsibility. Cambridge, MA: MIT Press

Nichols, S., \& Knobe, J. (2007). Moral responsibility and determinism: The cognitive science of folk intuitions. Nôus 41(4), 663-685.

Noble, K. G., Houston, S. M., Brito, N. H., Bartsch, H., Kan, E., Kuperman, J. M., ... \& Schork, N. J. (2015). Family income, parental education and brain structure in children and adolescents. Nature Neuroscience, 18(5), 773-778.

Paulhus, D. L., \& Carey, J. M. (2011). The FAD-Plus: Measuring lay beliefs regarding free will and related constructs. Journal of Personality Assessment, 93(1), 96-104.

Pew Research Center. (2014). 2014 Political Polarization and Typology Survey [data file] (Tech. Rep.). (Available at http://www.people-press.org/2014/03/16/2014-political-polarization-survey/)

Pinker, S. (2003). The blank slate: The modern denial of human nature. Penguin.

Paulhus, D. L., \& Carey, J. M. (2011). The FAD-Plus: Measuring lay beliefs regarding free will and related constructs. Journal of Personality Assessment, 93, 96-104.

Raby, K. L., Roisman, G. I., Fraley, R. C., \& Simpson, J. A. (2015). The enduring predictive significance of early maternal sensitivity: Social and academic competence through age 32 years. Child Development, 86(3), 695-708.

Rai, T. S., \& Holyoak, K. J. (2013). Exposure to moral relativism compromises moral behavior. Journal of Experimental Social Psychology, 49, 995-1001.

Rothbard, M. N. (1978). For a new liberty: The libertarian manifesto. Ludwig von Mises Institute.

Rotter, J. B. (1966). Generalized expectancies for internal versus external control of reinforcement. Psychological Monographs: General and Applied, 80(1), 1.

Saint-Paul, G. (2011). The tyranny of utility: Behavioral social science and the rise of paternalism. Princeton University Press.

Sarkissian, H., Chatterjee, A., De Brigard, F., Knobe, J., Nichols, S., \& Sirker, S. (2010). Is belief in free will a cultural universal? Mind \& Language, 25(3), 346-358.

Schultze-Kraft, M., Birman, D., Rusconi, M., Allefeld, C., Görgen, K., Dähne, S., Blankertz, B., \& Haynes, J. D. (2016) The point of no return in vetoing self-initiated movements. Proceedings of the National Academy of Sciences, $113(4)$, $1080-1085$.

Shariff, A. F., Greene, J. D., Karremans, J. C., Luguri, J. B., Clark, C. J., Schooler, J. W., Baumeister, R. F., \& Vohs, K. D. (2014). Free will and punishment: A mechanistic view of human nature reduces retribution. Psychological Science, 25(8), 1563-1570.

Singer, P. (2005). Ethics and intuitions. The Journal of Ethics, 9(3-4), 331-352.

Stroessner, S. J., \& Green, C. W. (1990). Effects of belief in free will or determinism on attitudes toward punishment and locus of control. The Journal of Social Psychology, 130(6), 789-799.

Sunstein, C., \& Thaler, R. (2003). Libertarian paternalism is not an oxymoron. The University of Chicago Law Review 70 , $1166-1187$.

Thaler, R. H., \& Benartzi, S. (2004). Save more tomorrow ${ }^{\mathrm{TM}}$ : Using behavioral economics to increase employee saving. Journal of Political Economy, $112(\mathrm{~S} 1)$, S164-S187.

Thaler, R., \& Sunstein, C. (2008). Nudge: Improving decisions about health, wealth, and happiness. New Haven, CT: Yale University Press.

Twenge, J. M., Zhang, L., \& Im, C. (2004). It's beyond my control: A cross-temporal meta-analysis of increasing externality in locus of control, 1960-2002. Personality and Social Psychology Review, 8(3), 308-319.

van Kleef, E., Otten, K., \& van Trijp, H. C. (2012). Healthy snacks at the checkout counter: A lab and field study on the impact of shelf arrangement and assortment structure on consumer choices. BMC Public Health, 12(1), 1072.

Waldman, D. A., Viney, W., Bell, P.A., Bennett, J.B., \& Hess, S. (1983). Internal and external locus of control in relation to beliefs in free will and determinism. Psychological Reports, 53, 631-634.

Wegner, D. (2002). The illusion of conscious will. Cambridge, MA: MIT Press. 